\title{
Factors Affecting Second Year Regular Biology Students' Participation in Group Activities in Wollega University
}

\author{
Hylemariam Mihiretie ${ }^{1}$, Alganesh Melese ${ }^{2}$, Fatuma Mohammad $^{2}$, Bedatu Reta $^{2}$, Melka Hika $^{3}$ \\ ${ }^{1}$ Department of Medical Laboratory Sciences, Wollega University, Nekemte, Ethiopia \\ ${ }^{2}$ Department of Biology, Wollega University, Nekemte, Ethiopia \\ ${ }^{3}$ Department of Education, Wollega University, Nekemte, Ethiopia
}

Email address:

hylemariam@gmail.com (H. Mihiretie)

\section{To cite this article:}

Hylemariam Mihiretie, Alganesh Melese, Fatuma Mohammad, Bedatu Reta, Melka Hika. Factors Affecting Second Year Regular Biology Students' Participation in Group Activities in Wollega University. Teacher Education and Curriculum Studies.

Vol. 2, No. 6, 2017, pp. 81-85. doi: 10.11648/j.tecs.20170206.11

Received: October 5, 2016; Accepted: October 18, 2016; Published: November 28, 2017

\begin{abstract}
Background: Group work is a method of teaching in which students are put in small groups, two to six, and work in cooperation with each other. But there are different factors that affect students' participation in group activities. This action research was intended to assess different factors affecting active participation of second year regular students in group activities. Methods: Institutional based cross sectional action research was conducted between April and May 2016. Study populations were all second year regular biology students (43 students) of Wollega University. Self-administered structured questionnaire was used to collect data. Data was analyzed using SPSS version 24 software and percentages were calculated. Data was presented using tables. Results: Analyzed data showed that the most important student related factors that respondents agreed to affect their active group participation include; lack of English language proficiency (28\%), reluctance in taking responsibilities (21\%), large group size (46\%), domination by active learners $(56 \%)$ and influence of mother tongue (21\%). Teacher related factors that affect students' active participation are lack of encouraging students, lack of control and guidance, non-grading of group activities and lack of teaching materials. Conclusion: Different factors like large group size, Dominance of active learners, Lack of language proficiency, Lack of teaching materials, Non-grading of group activities and Lack of encouraging the students were found to affect students' active participation. The intervention action plan developed in this action research project should be implemented in a course of study in which prevailing factors affecting students' active participation are similar to those herein identified. Sufficient guidance and counseling should be given to students in every group activities and learning issues.
\end{abstract}

Keywords: Action Research, Factors Affecting Active Participation, Wollega University

\section{Introduction}

Group work is a method of teaching in which students are put in small groups, two to six, and work in cooperation with each other [1]. Group work is a recommended method of teaching as opposed to teacher centered teaching [2-5]. It enhances students to practice the amount of quality language and provide cooperative atmosphere among learners. The situations in our schools seem to suggest that English communicative performance of students is low. Increasing low level of the students' speaking fluency is one of the importance of group work [6].
A study showed the importance of group work and noted that there is some resistance to get students into a group and low level of students' communicative competence due to students' negligence and lack of encouragement. The factors that impede teachers' group work implementation are found out to be students' use of mother tongue, disciplinary problems, motivation and fear. Academic status differences and domination are also major challenges of teachers in using group work [7-10].

The factors that affect students' verbal participation 
activities and the role of teachers to maximize the students' participation in group work are affected by insufficient time given to group work activities, poor seating arrangements and students negligence to perform their expected roles in group work activities [11-12]. It has been observed that some students in Wollega University are enrolled in a student centered teaching learning strategy where group activities play a major part. But the participation of all students in group activities is very poor. This action research study is aimed at addressing the issue of concern, and to come up with possible steps/action to improve the active participation of students in group activities.

This study is specifically focused on investigating the direct and indirect causes of poor group activity participation (focusing on the factors of interest), comparing and analyzing the difference between "actively participating students" and "passively participating students" enrolled in the biology department and finally to develop and implement an action plan that will produce a solution. The objective of this action research is; therefore, to improve second year biology students' participation in different group activities inside the class and outside of the class.

\section{Justification}

It has been observed that some students in Wollega University are enrolled in a student centered teaching learning strategy where group activities play a major part. But the participation of all students in group activities is very poor. This action research study is aimed at addressing the issue of concern, and to come up with possible steps/action to improve the active participation of students in group activities.

This study is specifically focused on investigating the direct and indirect causes of poor group activity participation (focusing on the factors of interest), comparing and analyzing the difference between "actively participating students" and "passively participating students" enrolled in the biology department and finally to develop and implement an action plan that will produce a solution.

\section{Methodology}

\subsection{Study Area and Period}

A cross sectional survey was conducted in Wollega University between April and May 2016. Study populations were all second year regular biology students (43 students) of Wollega University.

\subsection{Research Procedure}

\subsubsection{Problem Identification}

Poor interest and performance of students in actively participating in group activities was the problem identified.

\subsubsection{Data Collection and Analysis}

Students were informed about the objectives of the study before data collections were started. Quantitative data were collected through self-administered questionnaires.

\subsubsection{Proposal for Action}

Based on empirical data collected, seminar/discussions/workshops were designed and organized for the students; to alert, and orient them with strategies that can impart positively on their interest and performance towards active participation in group activities.

\subsubsection{Project Action Implementation}

Development of questionnaire, data analysis and interpretation, monitoring of strategic plan for student's active participation improvement, stating logical process/model for improving student's performance were taken by Hylemariam and Alganesh. Data collection, organizing workshop/seminar for students' improvement, collection of feed-back, report writing and final presentation was taken by Hylemariam, Alganesh, Fatuma, Bedhatu and Melka.

\subsubsection{Evaluation of Action}

Further data group activities inside and outside should be obtained from previous records and present studies of students-in-focus. Present and previous participation of students in group activities shall be compared and analyzed in order to access the effects of action-plan implemented on the sample-class of interest.

\subsubsection{Recommended Change}

A logical, sequential course of activities shall be proposed, and recommended to generally use as a model by teachers/instructors/departments to use for enhancing students' active participation, and to help students enrolled in a teaching method in which they lack or have lost interest.

\section{Result}

\subsection{Student Related Factors Affecting Active Participation}

In this study different factors affecting student's participations were identified. Table 1 shows that a little below half $(45 \%)$ of the students strongly agree that poor English language proficiency hinder their active participation in group activities while only $14 \%$ of them disagree with this idea. The most important student related factors that respondents agreed to affect their active group participation include; lack of English language proficiency (28\%), reluctance in taking responsibilities $(21 \%)$, large group size (46\%), domination by active learners $(56 \%)$ and influence of mother tongue (21\%). Twenty-five percent, $23 \%$ and $23 \%$ of the respondents strongly disagree that reluctance, influence of mother tongue and insufficient time affect active participation, respectively [Table 1]. 
Table 1. Student related factors affecting active participation in group activities in $2^{\text {nd }}$ year regular biology students, Wollega University, 2016.

\begin{tabular}{|c|c|c|c|c|c|c|c|c|c|c|}
\hline \multirow{3}{*}{ Students related factors } & \multicolumn{10}{|c|}{ Respondents responses } \\
\hline & \multicolumn{2}{|l|}{5} & \multicolumn{2}{|l|}{4} & \multicolumn{2}{|l|}{3} & \multicolumn{2}{|l|}{2} & \multicolumn{2}{|l|}{1} \\
\hline & № & $\%$ & № & $\%$ & № & $\%$ & № & $\%$ & № & $\%$ \\
\hline Lack of language proficiency & 19 & 45 & 12 & 28 & 6 & 14 & 1 & 2 & 5 & 11 \\
\hline Reluctance to work in groups & 7 & 16 & 9 & 21 & 14 & 32 & 11 & 25 & 2 & 4 \\
\hline Lack of experience & 11 & 25 & 5 & 11 & 15 & 35 & 5 & 11 & 7 & 16 \\
\hline Absence of leader & 3 & 7 & 5 & 11 & 5 & 11 & 3 & 7 & 27 & 63 \\
\hline Large group size & 17 & 39 & 20 & 46 & 2 & 4 & 2 & 4 & 2 & 4 \\
\hline Improper group composition & 5 & 11 & 5 & 11 & 14 & 32 & 2 & 4 & 17 & 39 \\
\hline Domination by active learner & 8 & 18 & 24 & 56 & 5 & 11 & 2 & 4 & 4 & 9 \\
\hline Nature of task & 8 & 18 & 8 & 18 & 19 & 45 & 8 & 18 & 0 & 0 \\
\hline Shyness & 5 & 11 & 4 & 9 & 17 & 39 & 2 & 4 & 15 & 35 \\
\hline Mother tongue influence & 12 & 28 & 9 & 21 & 3 & 7 & 10 & 23 & 9 & 21 \\
\hline Unavailability of text books & 2 & 4 & 5 & 11 & 8 & 18 & 5 & 11 & 23 & 53 \\
\hline Insufficient time & 6 & 14 & 8 & 18 & 13 & 30 & 10 & 23 & 6 & 14 \\
\hline Lack of interest to share knowledge & 7 & 16 & 7 & 16 & 4 & 9 & 3 & 7 & 22 & 51 \\
\hline
\end{tabular}

Key: $5=$ strongly agree, $4=$ =agree, $3=$ disagree, $2=$ strongly disagree, $1=$ undecided

As shown in table 1 above, large group size also affects student's participation in group activities. Accordingly, 39\% of students strongly agree and $46 \%$ of students agree with the idea that large group size is the main factor affecting their participation. From that, the most problem faced were; occurrence of dependency on the leader, member's shyness of each other and lack of confidence to express their opinion.

According to the data gathered from respondents through questioner and interview next to large group size, most of the students did not participate in group work due to lack of language proficiency. $45 \%$ strongly agree and $28 \%$ of respondents agree with Lack of language proficiency is the dominant reason for why they did not actively participate in group work. Because, they think that if they fell to talk English fluently somebody laugh to them, most of them prefer to be dormant rather than share their idea whenever it is right or wrong. Beside fear to give their idea on the task given in group, majority of them could not understand even things written in English and their efficiency towards participation in group discussion were retarded.

From the selected students $18 \%$ \& $56 \%$ of them strongly agree and agree respectively, on that student's participation to group activities affected largely by dominance of active learners. Because, the active students have their own confidence and they don't believe that, as the slow learner's idea add any value on their work. As a result, they don't want to waste their time with them.

\subsection{Teacher Related Factors Affecting Students' Active Participation}

Table 2 below shows that $21 \%$ and $23 \%$ of the respondents disagree and strongly disagree that teachers' failure to give clear explanation of the tasks affect students' active participation, respectively which indicates that teachers clearly share tasks to the students. Moreover, $32 \%$ and $23 \%$ of the students strongly agree that lack of teaching experience and lack of guidance, respectively do not have such a significant impact on students' active participation.

Teacher related factors that affect students' active participation are lack of encouraging students, lack of control and guidance, non-grading of group activities and lack of teaching materials [Table 2].

Table 2. Teacher related factors affecting active participation in group activities in $2^{\text {nd }}$ year regular biology students, Wollega University, 2016.

\begin{tabular}{|c|c|c|c|c|c|c|c|c|c|c|}
\hline \multirow{3}{*}{ Teachers associated factors } & \multicolumn{10}{|c|}{ Respondents responses } \\
\hline & \multicolumn{2}{|l|}{5} & \multicolumn{2}{|l|}{4} & \multicolumn{2}{|l|}{3} & \multicolumn{2}{|l|}{2} & \multicolumn{2}{|l|}{1} \\
\hline & № & $\%$ & № & $\%$ & № & $\%$ & № & $\%$ & № & $\%$ \\
\hline Failure to give clear explanation of tasks & 2 & 5 & 4 & 9 & 9 & 21 & 10 & 23 & 18 & 42 \\
\hline Lack of teaching experience & 5 & 11 & 4 & 9 & 9 & 21 & 14 & 32 & 11 & 23 \\
\hline Lack of encouraging the students & 6 & 14 & 9 & 21 & 7 & 16 & 8 & 18 & 13 & 30 \\
\hline Lack of control, guidance and checking activities of groups & 5 & 11 & 7 & 16 & 10 & 23 & 11 & 23 & 10 & 23 \\
\hline Non-grading of group activities & 6 & 14 & 9 & 21 & 9 & 21 & 5 & 11 & 14 & 32 \\
\hline
\end{tabular}

Key: $5=$ strongly agree, $4=$ agree, $3=$ disagree, $2=$ strongly disagree, $1=$ undecided

The table above shows that lack of teaching materials, non-grading of group activities and lack of encouraging the students were the major teacher related factors mentioned as a significant problem inhibiting students' active participation.

\subsection{Research Project Intervention Plan and Changes}

Based on empirical data collected, an intervention plan was designed for the students; to alert, and orient them with 
strategies that can help impart positively on their academic interest and performance towards active participation in group activities. The structured plan is shown in Table 3 below. After a better understanding of the magnitude of the factors affecting active participation in group activities of the students; problems to be addressed were categorized into 6 major areas, namely: lack of interest, poor English language proficiency, large group size, lack of guidance and control, non-grading of group activities and domination by active learners. The actions taken by respective members of the project group are also highlighted in the table.

Table 3. Action plan on enhancing students' performance towards active participation in group activities.

\begin{tabular}{|c|c|c|c|}
\hline Identified problems & Actions to be taken & Responsible person/s & Date to be carried out \\
\hline Lack of interest & $\begin{array}{l}\text { Exposing students to repeated group activities } \\
\text { Advising students to actively participate in group } \\
\text { activities }\end{array}$ & $\begin{array}{l}\text { Hylemariam } \\
\text { Alganesh } \\
\text { Fatuma } \\
\text { Bedhatu }\end{array}$ & $\begin{array}{l}\text { Starting from May } 2016 \\
\text { to their graduation }\end{array}$ \\
\hline Poor English language proficiency & $\begin{array}{l}\text { Exposing students to repeated presentations and } \\
\text { providing them with materials that enhance their } \\
\text { English language proficiency }\end{array}$ & $\begin{array}{l}\text { Hylemariam } \\
\text { Alganesh } \\
\text { Fatuma } \\
\text { Bedhatu }\end{array}$ & $\begin{array}{l}\text { Starting from May } 2016 \\
\text { to the end of the } \\
\text { semester }\end{array}$ \\
\hline Large group size & $\begin{array}{l}\text { Reducing the number of students per group with the } \\
\text { maximum of five }\end{array}$ & $\begin{array}{l}\text { Hylemariam } \\
\text { Alganesh } \\
\text { Fatuma } \\
\text { Bedhatu }\end{array}$ & $\begin{array}{l}\text { Starting from May } 2016 \\
\text { to the end of the } \\
\text { semester }\end{array}$ \\
\hline Domination by active learners & $\begin{array}{l}\text { Controlling dominants and encouraging passive } \\
\text { learners through making participations turn by turn }\end{array}$ & $\begin{array}{l}\text { Hylemariam } \\
\text { Alganesh } \\
\text { Fatuma } \\
\text { Bedhatu }\end{array}$ & $\begin{array}{l}\text { Starting from May } 2016 \\
\text { to the end of the } \\
\text { semester }\end{array}$ \\
\hline $\begin{array}{l}\text { Lack of teacher guidance and } \\
\text { control }\end{array}$ & $\begin{array}{l}\text { Controlling any group activity be it inside class or out } \\
\text { Guiding students on how to proceed through all group } \\
\text { activities }\end{array}$ & $\begin{array}{l}\text { Hylemariam } \\
\text { Alganesh } \\
\text { Fatuma } \\
\text { Bedhatu }\end{array}$ & $\begin{array}{l}\text { Starting from May } 2016 \\
\text { to the end of the } \\
\text { semester }\end{array}$ \\
\hline Non-grading of group activities & Grading all group activities accordingly & $\begin{array}{l}\text { Hylemariam } \\
\text { Alganesh } \\
\text { Fatuma } \\
\text { Bedhatu }\end{array}$ & $\begin{array}{l}\text { Starting from May } 2016 \\
\text { to the end of the } \\
\text { semester }\end{array}$ \\
\hline Supervising all activities & $\begin{array}{l}\text { Supervising and evaluating all activities undertaken } \\
\text { by the researchers. }\end{array}$ & Melka Hika & $\begin{array}{l}\text { Starting from proposal } \\
\text { development }\end{array}$ \\
\hline
\end{tabular}

\section{Discussion}

Group work is a recommended method of teaching as opposed to teacher centered teaching [2-5]. It enhances students to practice the amount of quality language and provide cooperative atmosphere among learners. The situations in our schools seem to suggest that English communicative performance of students is low. Increasing low level of the students' speaking fluency is one of the importance of group work [6]. We have conducted an action research regarding the factors that affect students' active participation in group work in Wollega University, Ethiopia. We grouped these factors into two; student related and teacher related.

Our results showed that the most important student related factors that respondents agreed to affect their active group participation include; lack of English language proficiency (28\%), reluctance in taking responsibilities $(21 \%)$, large group size $(46 \%)$, domination by active learners $(56 \%)$ and influence of mother tongue (21\%). Twenty-five percent, $23 \%$ and $23 \%$ of the respondents strongly disagree that reluctance, influence of mother tongue and insufficient time affect active participation, respectively. This is partly similar with other researches $[9,10]$ who reported actors that impede teachers' group work implementation are students' use of mother tongue, disciplinary problems, motivation and fear as factors negatively affecting group work. Another research declared academic status differences in participation and domination as major challenges of teachers in using group work which agrees with our results.

Whenever the number of students in a group exceeds six, the probability of getting chance to share ideas will minimize. Atkins et al (1996) [13], also suggests that group work should be a collection of three to four students working together collaboratively and it should not exceed six. From these we can understand that many of the scholars suggest four to six as preferable group size.

From the selected students, $18 \% \& 56 \%$ of them strongly agree and agree respectively, on that student's participation to group activities affected largely by dominance of active learners. Because, the active students have their own confidence and they don't believe that, as the slow learner's idea add any value on their work. As a result, they don't want to waste their time with them. According to Cohen (1972) [14] a student who is seen as best in reading is likely to dominate group activity, on the other hand, a student who is seen as poor in reading is very likely to be relatively inactive in other tasks. Academic status also creates a problem when it spreads to a wide range of activities, which do not require the skill that has made up the status. However, such kind of conditions could be improved if the group has a responsible group leader, because the group leader allows equal opportunity and time for all group members. 
Teacher related factors that affect students' active participation are lack of encouraging students, lack of control and guidance, non-grading of group activities and lack of teaching materials. Additionally, lack of teaching materials, non-grading of group activities and lack of encouraging the students were the major teacher related factors mentioned as a significant problem inhibiting students' active participation. This result exactly agrees with a study done in Ethiopia [15].

After the intervention of action plan on enhancing students' active participation of second year regular biology students, the following changes were observed:

a Increased active participation: They got the basic skill of handling proactive participation and start giving time on exercising active participation in groups.

b Students start appreciating active group participation when they just begin relating the lecture method of teaching with student centered learning.

c And finally students develop group working and get going helping each other in solving problems and doing group activities.

\section{Conclusion}

From the above findings there are different factors affecting students' group participation specifically in case of soil science. Those factors were categorized as student related factors and teachers related factors. Among the student related factors, large group size, Dominance of active learners, Lack of language proficiency and Mother tongue influence were listed as the most problem, while Lack of teaching materials, Non-grading of group activities and Lack of encouraging the students were mentioned in the side of teachers related factors.

\section{Recommendations}

a The intervention action plan developed in this action research project should be implemented in a course of study in which prevailing factors affecting students' active participation are similar to those herein identified.

b Sufficient guidance and counseling should be given to students in every group activities and learning issues.

c English language proficiency laboratories and materials should be available in the university to increase students' language skill

d Students should be regularly motivated and encouraged to always perform at their best possible.

e Students should be empowered with effective learning methods like group activities.

f Teachers should guide and control group activities and grade every group activity so as to help students increase their interest in group activities and optimize equal participation of all students in group activities

\section{Competing Interests}

All authors declare that they have no conflict of interest associated with the publication of this manuscript.

\section{Acknowledgements}

We would like to thank the Wollega University for financial and administrative support, all study participants for their cooperation, and administrative and academic staffs of the department of Biology. Moreover, we would like to thank the data collectors and study participants without whom the research would not be a reality.

\section{References}

[1] Getachew Liben (2008). An Assessment of some factors that affect students' verbal participation in group work. Addis Ababa [Unpublished Ma thesis].

[2] Larsen- Freeman D (2000). Techniques and Principles in Language Teaching. Oxford: CUP.

[3] Nunan D (1992). Research Methods in Language Learning. Cambridge: CUP.

[4] Richards J. C and T. S. Rodgers (1986). Approaches and Methods in Language teaching. Cambridge: CUP.

[5] Long, M, H. and PA Porter (1985). Group work, Interlanguage Talk and second language Acquisition. TESOL Quarterly: $19 / 2$.

[6] Alamirew Gebre Mariam (1992). The Applicability of Group work in learning English. Addis Ababa University [Unpublished MA Thesis].

[7] Mehari Abreha (2011). The Implementation of Group work in Hawassa Primary Government schools grade 8 in focus. Addis Ababa University. [Unpublished MA thesis].

[8] Ministry of Education (2011). Secondary school Standard. Ministry of Education press [unpublished].

[9] Girma. G (2005). A study of Secondary School English Language Teachers' implementation of Methodological innovations: The teaching of Grammar in focus. Addis Ababa University [unpublished PHD dissertation].

[10] Adam Mohammed (2007). Study on the Challenges and Opportunities of Using Group Work in EFL Class With Reference to Grade 9 Dire Dawa Comprehensive School. Addis Ababa University (Unpublished MA Thesis).

[11] Getachew Liben (2008). An Assessment of some factors that affect students' verbal participation in group work. Addis Ababa (Unpublished Ma thesis).

[12] Gebrewahid Tsige (2011). A study on the Perception and Roles of EFL students in Group Work Implementation. Addis Ababa University (Unpublished MA thesis).

[13] Atkins. Hailom, B. and Nuru, M. (1996). Skills Development Methodology (Part 2). Addis Ababa University: Addis Ababa University Printing press.

[14] Cohen, E. G. (1972). Designing Group Works: Strategies for the Heterogeneous classrooms. New York: Teaching Collage press.

[15] Mesfin Kebede (2012). Constraints Encountered in Group Work in Teaching English Language at Adea Model Secondary School: Grade Nine in Focus. [Unpublished MA thesis]. 